\title{
POTENSI JAMUR ENDOFIT TANAMAN KARET DALAM MENGHAMBAT PERTUMBUHAN JAMUR AKAR PUTIH (Rigidoporus microporus) SECARA IN VITRO
}

\author{
Widya Lestari dan Aini Qomariah Manurung \\ Program Studi Agroteknologi Sekolah Tinggi Ilmu Pertanian Labuhan Batu \\ Jln. SM. Raja No 126 A Aek Tapa Labuhanbatu Sumatera Utara \\ e-mail : widya.chubby@yahoo.co.id
}

\begin{abstract}
One of the environmentally friendly control alternatives that can be done, namely by utilizing biological agents in the form of endophytic fungi that are antagonistic. This study aims to study and obtain information about the potential of endophytic fungi in inhibiting white root fungi in vitro. Endophytic fungi isolation is carried out by sterilizing the surface of the stem of the rubber plant and culture it on agar nutrient media. Five endophytic bacterial isolates were obtained from the roots of rubber plants, respectively: JEBO1, JEB02, JEB03, JEBO4 and JEB05. Fungal isolates were tested antagonistically in vitro against Rigidoporus microporus. Two fungal isolates, JEBO1 and JEBO2 showed the best antagonist in inhibiting the growth of pathogenic fungi Rigidoporus microporus in vitro.
\end{abstract}

Keywords: endophytic fungi, in vitro, Rigidoporus microporus, rubber plants (Hevea brasilliensis

\section{PENDAHULUAN}

Jamur akar putih (Rigidoporus microporus) merupakan jamur patogen yang menyebabkan kerusakan pada karet. Jamur ini menyerang bagian akar tanaman karet. Serangan jamur patogen tersebut mengakibatkan kerugian yang sangat besar bagi para petani. Untuk itu diperlukan suatu penanggulangan yang efektif. Selama ini telah banyak dilakukan pengendalian fungi patogen pada tanaman secara kimiawi, akan tetapi menimbulkan efek negatif terhadap lingkungan. Untuk itu perlu diupayakan suatu alternatif pengendalian secara biologi dengan menggunakan mikroba antagonis atau menggunakan metabolit antimikroba yang dihasilkan.
Usaha penanggulangan penyakit tanaman secara biologis mempunyai peluang yang cukup besar karena organismenya telah tersedia di alam dan aktivitasnya dapat distimulasi dengan memodifikasi lingkungan maupun tanaman inang. Keuntungan dalam menggunakan mikroorganisme antagonis sebagai pengendalian biologis antara lain: aman terhadap lingkungan, tidak ada efek residu, aplikasinya bersifat berkelanjutan karena yang digunakan organisme hidup yang dapat memperbanyak diri sehingga dapat mengurangi aplikasi yang berulang-ulang (Cook dan Baker, 1989). 
Hampir di setiap bagian tanaman ditemukan adanya jamur endofit, baik pada daun, akar maupun batang. Dalam beberapa tahun terakhir, pengaplikasian mikroba endofit sebagai pengendali biologis telah menjadi alternatif untuk menggantikan peran pengendali kimia seperti pestisida. Penggunaan agen biologis ini secara alami mampu mengendalikan populasi hama, meningkatkan produksi tanaman dan merupakan pilihan yang baik bagi resistensi penyakit dan juga ramah lingkungan (Procopio et al., 2009).

Tanaman tingkat tinggi mengandung beberapa mikroba endofit yang menghasilkan metabolit sekunder sebagai bentuk pertahanan terhadap mikroba patogen (Radji, 2005). Tanaman karet memiliki bakteri endofit, karet merupakan pohon yang tumbuh tinggi dan memiliki batang yang cukup besar. Tinggi pohon dewasa dapat mencapai 15-25 m. Batang karet tumbuh lurus ke atas dan cenderung miring ke arah utara. Bagian batang inilah yang mengandung getah atau lateks. Penelitian ini diperlukan untuk mengetahui potensi jamur endofit yang ada pada akar tanaman karet sebagai agen pengendalian hayati.

\section{METODE PENELITIAN}

\section{Waktu dan Tempat}

Penelitian ini dilakukan dari bulan Juni 2018 sampai November 2018. Pengambilan sampel dilakukan di Perkebunan Rakyat Marbau Selatan. Penelitian dilakukan di Laboratorium Mikrobiologi, Departemen Biologi, Fakultas Matematika dan Ilmu Pengetahuan Alam, Universitas Sumatera Utara, Medan.

\section{Teknik Pengambilan Sampel}

Pengambilan sampel tanaman dilakukan di kebun rakyat Marbau Selatan, sampel batang yang diambil dari bagian tanaman sehat. Sampel batang dibawa ke Laboratorium untuk diisolasi jamur endofitnya. Isolasi jamur endofit dari batang dilakukan dengan metode sterilisasi permukaan menurut metode Radu and Kqueen (2002).

Sampel yang diambil dari lokasi dimasukkan ke dalam plastik diletakkan di dalam termos yang berisi es batu, kemudian sampel dibawa ke laboratorium mikrobiologi untuk isolasi bakteri endofit. Tahap awal yang dilakukan adalah mencuci batang dengan air mengalir selama 20 menit. Sterilisasi bagian permukaan akar dilakukan dengan cara merendamnya di dalam larutan secara berturut- turut: etanol $75 \%$ selama 2 menit, larutan sodium hipoklorit 5,3\% selama 5 menit dan etanol $75 \%$ selama 30 detik.

Selanjutnya akar dibilas dengan aquadest steril, setelah kering bagian ujung kiri dan kanan batang dipotong $1 \mathrm{~cm}$, kemudian masing-masing batang dipotong membujur dan diletakkan di permukaan media PDA dengan posisi bekas potongan ke arah media, kemudian diinkubasi pada suhu ruang selama 5 hari. Koloni yang muncul disubkultur ke media PDA yang baru untuk dimurnikan.

\section{Uji in vitro Jamur Endofit Terhadap Rigidoporus microporus}

Uji potensi dilakukan untuk melihat kemampuan jamur endofit dalam menghambat pertumbuhan Rigidoporus microporus. Biakan kultur JAP yang sudah 
diremajakan diambil dengan cork borer, lalu diinokulasikan pada bagian tengah media PDA dengan jarak $3,5 \mathrm{~cm}$ dari cakram tempat inokulum isolat bakteri lalu biakan tersebut diinkubasi selama 72 jam pada suhu ruang. Metode pengukuran zona hambat jamur endofit terhadap koloni jamur patogen berdasarkan (Suryanto dan Munir, 2006) (Gambar 1).

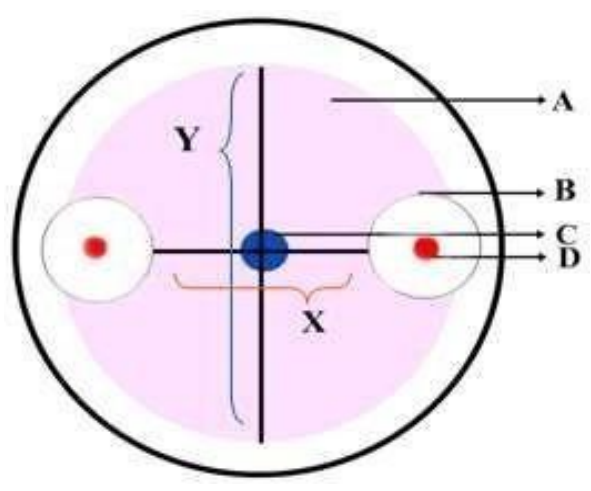

Gambar 1. A. koloni jamur patogen, B. zona hambat jamur endofit terhadap koloni fungi patogen, C. titik tengah jamur endofit diletakkan, D. koloni jamur endofit, X. diameter koloni jamur $R$. microporus yang terhambat pertumbuhannya, Y. Diameter koloni jamur R. microporus normal

Persentase penghambatan (\%) didapat dengan rumus:

$$
P P(\%)=\frac{\text { Tepi miselium }(\text { kontrol })-\text { Tepi miselium }}{\text { Tepi miselium }(\text { kontrol })} \times 100 \%
$$

\section{Karakterisasi dan Identifikasi Isolat Jamur Endofit}

Hasil seleksi isolat jamur endofit diperoleh 5 isolat yang memiliki potensi daya hambat terhadap jamur akar putih. Selanjutnya ke-5 isolat tersebut diamati karakteristik morfologinya baik secara mikroskopis maupun makroskopis. Identifikasi dilakukan dengan metode biakan slide (slide culture) untuk mengetahui genus masing-masing isolat.

\section{HASIL DAN PEMBAHASAN}

Isolat jamur endofit yang telah diperoleh dari sampel batang, kemudian dimurnikan. Selanjutnya dilakukan pengujian secara in vitro untuk mengetahui daya hambat (antagonisme) terhadap
Rigidoporus microporus. Hasil pengamatan daya hambat isolat jamur terhadap patogen Rigidoporus microporus menunjukkan bahwa setiap isolat mempunyai kemampuan daya hambat yang berbeda-beda. Isolat jamur yang memiliki daya hambat tinggi merupakan isolat antagonis yang pertumbuhan koloninya lebih cepat dibandingkan koloni patogen dan tampak perkembangan koloni antagonis dapat menutupi dan menekan perkembangan koloni patogen. Cook dan Baker (1989) menjelaskan bahwa salah satu syarat suatu organisme disebut sebagai agens hayati adalah apabila mempunyai kemampuan antagonisme atau kemampuan menghambat perkembangan dan pertumbuhan organisme lainnya. Mekanisme biokontrol adalah 
melemahkan atau membunuh patogen tanaman dengan perlawanan yaitu memparasit patogen secara langsung, memproduksi antibiotik (toksin), dan kemampuannnya dalam kompetisi ruang dan nutrisi. Jamur Endofit memproduksi enzim untuk melawan komponen sel jamur patogen, menginduksi respon ketahanan tanaman, dan produksi metabolisme tanaman dalam menstimulasi perkecambahan spora patogen (Tabel 1).

Tabel 1. Daya hambat isolat jamur endofit tanaman karet Terhadap Rigidoporus microporus

\begin{tabular}{ccc}
\hline NO & Kode Isolat Daya Hambat $(\boldsymbol{\%})$ \\
\hline 1 & JEB01 & 65,2 \\
2 & JEB02 & 75,4 \\
3 & JEB03 & 63,3 \\
4 & JEB04 & 60,5 \\
5 & JEB05 & 20,3 \\
\hline
\end{tabular}

Menurut Bakri (2009), isolat jamur tersebut memiliki kemampuan antagonistik yang ditandai dengan adanya penghambatan miselium jamur patogen tanaman dan pada akhirnya pertumbuhan hifa menipis, mengering dan mengalami abnormalitas. Kecepatan pertumbuhan jamur endofit merupakan indikator mekanisme kompetisi ruang dan nutrisi dengan jamur Rigidoporus microporus. Semakin cepat pertumbuhan jamur endofit maka semakin efektif menekan pertumbuhan jamur patogen. Kecepatan pertumbuhan koloni jamur merupakan salah satu faktor penting dalam menentukan potensinya sebagai agens hayati terhadap patogen. Elbert et al. (2007) menyatakan bahwa pertumbuhan koloni jamur yang dihasilkan memiliki peranan penting dalam proses siklus hidupnya karena spora/konidia merupakan alat reproduksi aseksual, penyebaran, dan pertahanan hidup jamur pada lingkungannya.

\section{Mekanisme Penghambatan Jamur} Endofit terhadap Rigidoporus microporus

$\begin{array}{ccr}\text { Hasil pengamatan } & \text { secara } \\ \text { mikroskopis terhadap mekanisme }\end{array}$ penghambatan jamur antagonis terhadap patogen $R$. microporus terlihat dalam pengamatan hifa jamur $R$. microporus Semua jamur antagonis yang dievaluasi mempunyai satu atau lebih mekanisme penghambatan, yaitu kompetisi, antibiosis, dan parasitisme.

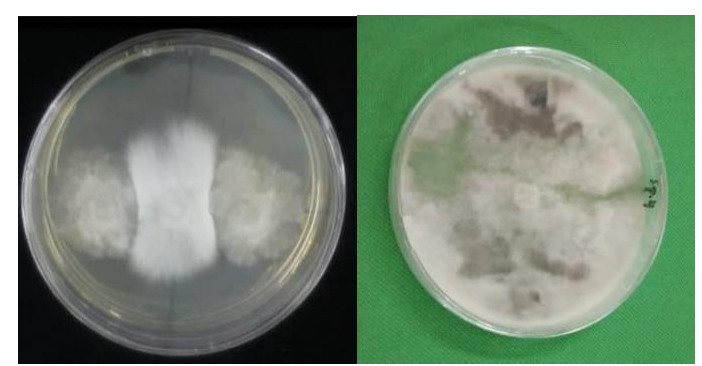

Gambar 2. Uji antagonis jamur endofit dengan jamur patogen Rigidoporus microporus

Tabel 2. Deskripsi gejala antagonis yang terjadi antara isolat jamur endofit dari batang tanaman karet dengan Rigidoporus microporus

\begin{tabular}{|c|c|}
\hline $\begin{array}{l}\text { Kode } \\
\text { Isolat }\end{array}$ & Gejala Antagonis \\
\hline JEB01 & $\begin{array}{l}\text { Pertumbuhan jamur patogen terhambat, } \\
\text { hifa lisis }\end{array}$ \\
\hline JEB02 & $\begin{array}{l}\text { Pertumbuhan jamur patogen terhambat, } \\
\text { hifa bengkok }\end{array}$ \\
\hline JEB03 & $\begin{array}{l}\text { Pertumbuhan jamur patogen terhambat, } \\
\text { hifa menggulung }\end{array}$ \\
\hline JEB04 & $\begin{array}{l}\text { Pertumbuhan jamur patogen terhambat, } \\
\text { hifa mengecil }\end{array}$ \\
\hline JEB05 & $\begin{array}{l}\text { Pertumbuhan jamur patogen terhambat, } \\
\text { hifa menggulung }\end{array}$ \\
\hline
\end{tabular}



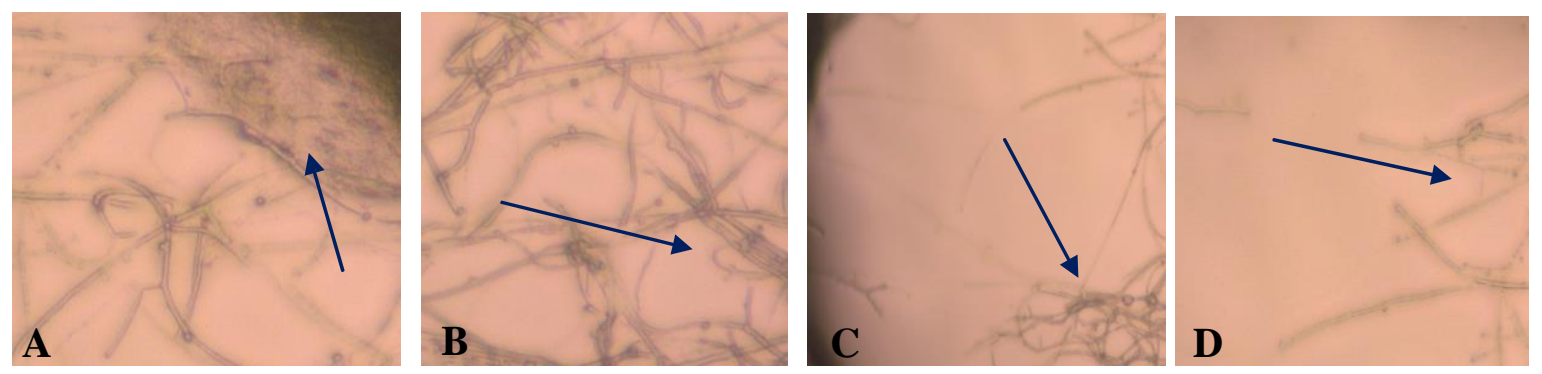

Gambar 3. Respon hifa Rigidoporus microporus setelah uji antagonis dengan jamur endofit yang diisolasi dari batang tanaman karet (A) Hifa Lisis, (B). Hifa Bengkok, (C). Hifa Menggulung, (D). Hifa Mengecil

Jamur endofit dari jenis Trichoderma yang mempunyai mekanisme kompetisi dan parasitisme, umumnya memiliki spektrum penghambatan yang lebih luas dan lebih kuat sehingga menyebabkan patogen tidak dapat tumbuh. Aktivitas parasitisme dari jamur antagonis jenis Trichoderma menghasilkan senyawa kimia yang bersifat toksik dan enzim yang mampu mendegradasi sel patogen.

Antibiosis adalah mekanisme antagonism yang melibatkan hasil metabolit penyebab lisis, enzim, senyawa folatil dan non-folatil atau toksin yang dihasilkan oleh suatu mikroorganisme. Meskipun mikoparasitisme dianggap sebagai mekanisme antagonism yang utama, tetapi penelitian lebih lanjut mengungkapkan bahwa metabolit sekunder yang dihasilkan Trichoderma spp. juga berperan penting dalam aktifitas antijamurnya (Chet et al., 2005).

Purwantisari dan Hastuti (2009), melaporkan bahwa semakin cepat pertumbuhan jamur antagonis, maka pertumbuhan jamur patogen akan semakin terdesak karena kehabisan ruang tumbuh. Mikroba endofit dapat melindungi tumbuhan inang dari serangan patogen dengan senyawa yang dikeluarkan. Senyawa yang dikeluarkan mikroba endofit berupa senyawa metabolit sekunder yang merupakan senyawa bioaktif dan dapat berfungsi untuk membunuh patogen (Prihatiningtias dan Wahyuningsih, 2014).

\section{KESIMPULAN}

Diperoleh 5 isolat jamur endofit yang diisolasi dari batang tanaman karet: JEB01, JEB02, JEB03, JEB04 dan JEB05. Isolat JEB01 dan JEB02 menunjukkan daya antagonis terbaik dalam menghambat pertumbuhan jamur patogen Rigidoporus microporus secara in vitro.

\section{DAFTAR PUSTAKA}

Bakri, M. 2009. Isolasi dan Uji Kemampuan Antifungal Fungi Endofit dari Tanaman Andaliman (Zanthoxylum acanthopodium DC.) Terhadap Fungi Perusak Makanan. Skripsi. USU. Medan

Chet I, N. Benhamou, S. Haran. 2005. Mycoparasitism and Lytic Enzymes. In Harman, G.E. and C. P. Kubicek (Eds), Trichoderma and Gliocladium enzymes biologica 1 control and commercial applications Volume 2. Taylor and Francis. London. 
Cook RJ, Baker KF. 1989. The Nature of Practice of Biological Control of Plant Pathogens. The APS Press, St. Paul, Minnesota. 53 p.

Elbert W, Taylor PE, Andreae, MO, Pöschl U. 2007. Contribution of Fungi to Primary Biogenic Aerosols in The Atmosphere: Wet and Dry Discharged Spores, Carbohydrates and Inorganic Ions. Atmos. Chem. Phys.7(4569-4588).

Prihatiningtias W, M.S.H. Wahyuningsih. 2014. Prospek Mikroba Endofit sebagai Sumber Senyawa Bioaktif. Fakultas Farmasi UGM. Yogyakarta.

Procopio REL, Araujo W, Maccheroni Jr, Azevedo JL. 2009. Characterization of an Endophytic Bacterial Community Associated with Eucalyptus spp. Genet Mol Res 8 (4): 1408-1422.

Purwantisari S, R.B. Hastuti. 2009. Uji Antagonisme Jamur Patogen Phytophthora infestans Penyebab Penyakit Busuk Daun dan Umbi Tanaman Kentang dengan Menggunakan Trichoderma spp. Isolat Lokal. Bioma. 11(1): 24-32.

Radu S, Kqueen CY. 2002. Preliminary Screening of Endophytic Fungi From Medicinal Plants in Malaysia for Antimicrobial and Antitumor Activity. Malaysian Journal of Medical Science. 9(2): 23-33.
Radji, M. 2005. Peranan bioteknologi dan mikroba endofit dalam pengembangan obat herbal. Majalah Ilmu Kefarmasian. 2: 118-121.

Suryanto D, Munir E. 2006. Potensi Isolat Bakteri Kitinolitik Lokal untuk Pengendalian Hayati Jamur. Prosiding Seminar Hasil-hasil Penelitian USU 2006. 